ROCZNIK PRZEMYSKI t. 57

LITERATURA I JEZYK z. 2 (25) 2021

PIOTR BOREK (Kraków)

ORCID: 0000-0003-3031-7722

\title{
NA TROPACH IDEI WOLNOŚCI W LITERATURZE STAROPOLSKIEJ
}

Najnowsza książka Krzysztofa Koehlera, zatytułowana Punkty krystalizacji. Szkice o literaturze staropolskiej ${ }^{1}$, obejmuje zbiór esejów oraz studiów analitycznych poświęconych eksplikacji literatury dawnej. Główną osią wywodu okazuje się ,polskość”, której przejawów autor poszukuje między innymi w dyskursie wolnościowym, obecnym już w najstarszych przekazach kronikarskich.

Tytuł cyklu szkiców ujęty został w metaforę, której sens badacz wyjaśnił następująco: „Oczywiście termin użyty przeze mnie jest swoistą metaforą tekstów kluczowych, w których dochodzi do głosu owa właśnie krystalizacja stanu świadomości wspólnotowej danego czasu. Dzięki wielowiekowej lekturze tego typu wypowiedzi «krystalizacyjnych» mamy do czynienia z narastającą w czasie czy nawarstwiającą się refleksją" (s. 13). Autor tropi zatem literackie świadectwa dokumentujące narastający stan ,samozrozumienia wspólnoty odbiorców kultury piśmienniczej”, która w kolejnych wiekach coraz intensywniej manifestowała poczucie „polskości”. Diachroniczne spojrzenie na dziesiątki utworów literackich doprowadziło K. Koehlera do wniosku, iż występowały w piśmiennictwie staropolskim formuły słowne, a nawet całe ciągi narracyjne, które miały niebagatelny wpływ na formowanie polskiej wspólnoty, pojmowanej jako zbiór jednostek o „świadomości wspólnotowej danego czasu”. W tym kontekście warto odnieść się do zadeklarowanej we wstępie metodologii interpretowania tekstów dawnych przez autora Punktów krystalizacji. Otóż zdecydowanie odcina się on od teorii postmodernistycznych, postkolonialnych i marksistowskich (np. Stanley Fish, Antonio Gramsci), mających za główny cel „dewastację dziedzictwa i tradycji”, a także relatywizm historyczny, służący promowaniu narracji krytycznych i alternatywnych. Filolog rekapituluje w tym przypadku spostrzeżenia Haydena White'a, który stwierdził, iż „postmodernistyczna myśl historyczna jest zorientowana na teraźniejszość i zainteresowana przeszłością o tyle, o ile może być

${ }^{1}$ K. Koehler, Punkty krystalizacji. Szkice o literaturze staropolskiej, Wydawnictwo Księgarnia Akademicka, Kraków 2020. 
ona wykorzystana na jej użytek"2. Dla Koehlera metoda postmodernistyczna, której podstawę stanowi nieufność do wszelkich dominujących i obowiązujących narracji, okazuje się mało przydatna, gdyż „stała się ona niejako chyba dyżurną metodologią wszelkich dociekań podważających przyjętą wykładnię dziejów spod znaku dziedzictwa i tradycji, przekształciła się w swoistą narrację wstydu..." (s. 11). Badacz stara się zadeklarować jako historyk idei, dla którego nieodzowny staje się sceptycyzm i ostrożność w rozkodowaniu dawnych tekstów kultury. $\mathrm{Z}$ tak pojmowanej pracy rozpoznawania przeszłości humanista czerpie pożytek dla pełniejszego zrozumienia teraźniejszości.

Naczelną ideę Punktów krystalizacji stanowi „trwanie wolności”, która zdaniem badacza winna być rozumiana nieco inaczej niż w kontekście narodowych zrywów i wywalczania jej, począwszy od XIX stulecia. Chodzi tu bowiem o koncepcję wolności, która była udziałem Polaków w wiekach wcześniejszych, co dokumentowali przede wszystkim pisarze renesansu i baroku³. Dla Koehlera przydatna okazuje się w tym przypadku wykładnia Quentina Skinnera, analizującego powiązania wolności z republikanizmem ${ }^{4}$. Był to inny model wolności, nawiązujący w swej istocie do tradycji starożytnych, głównie rzymskich. Jak zauważył autor szkiców, dziś mało kto ma świadomość, iż pierwotnie Polacy nie walczyli o wolność: „Polacy wolność zagospodarowywali, urządzali, umieszczali się w rodzinie europejskich wspólnot politycznych przez wieki” (s. 9). Rekonstruując ideę wolnościową, utożsamianą z rdzeniem „polskości”, autor prześledził wybrane utwory staropolskie i dostrzegł w nich systematyczne nawarstwianie się refleksji o interesującym go zagadnieniu.

Spośród osiemnastu szkiców, jakie składają się na książkę Punkty krystalizacji, cztery początkowe dotyczą tekstów średniowiecznych, natomiast dalej ich proporcje układają się symetrycznie - po sześć poświęconych interpretacji utworów renesansowych i barokowych. Pracę domyka studium o Franciszku Karpińskim oraz posłowie Nie jesteśmy sami, w którym badacz odnosi się do spuścizny Adama Mickiewicza.

Partia średniowieczna, którą inicjuje studium o pierwszym zabytku kronikarskim autorstwa Anonima tzw. Galla, powiązana jest zasadniczo z kwestiami podmiotowości organizmu stosunkowo młodego państwa, a w związku z tym z namysłem nad usankcjonowaniem miejsca Polski na mapie Europy. Dla Koehlera fundamentalne znaczenie ma mit założycielski, a obok niego starożytne umiłowanie wolności, czemu Gall dał wyraz w przedmowie do księgi pierwszej kroniki, pisząc o pokojowym usposobieniu przodków, ale zarazem męstwie ujawnianym w wojnach obronnych („Kraj [...] otoczony przez tyle wyżej wspomnianych ludów chrześcijańskich i pogańskich i wielokrotnie napadany przez wszystkie naraz

${ }^{2}$ H. White, Przeszłość praktyczna, red. E. Domańska, tłum. J. Burzyński et al., Kraków 2014, s. 36.

${ }^{3}$ Por. K. Koehler, Rzeczpospolita. Obywatelskość. Wolność. Szkice o polskim pisarstwie politycznym XVI wieku, Warszawa 2016.

${ }^{4}$ Q. Skinner, Wolność przed liberalizmem, thum. A. Czarnecka, Torun 2013. 
i każdy z osobna, nigdy przecież nie został przez nikogo ujarzmiony w zupełności"s). Na podbudowie chorograficznej oraz niezależności politycznej od państw zachodnich Wincenty Kadłubek dokonał, jak chce badacz, dzieła stworzenia zarysu ustroju monarchicznego, z wyeksponowaniem zasad funkcjonowania państwa i cnót obywatelskich - a wśród nich sprawiedliwości jako dominanty etycznej. W kontekście idei „uwspólnotowienia” filolog rozpatruje Bogurodzicę, poszerzając pole obserwacji o Mazurek Dąbrowskiego, czyli tradycję hymniczną. Trzeba stwierdzić, iż to luźne zestawienie interpretacji odległych od siebie czasowo tekstów pokazuje odmienność sytuacji historycznej - w pierwszym przypadku modlitwy o dostatnie życie i radość zbawienia, a w drugim deklaracji niepodległościowej i zamanifestowania męstwa w obliczu zrzucania jarzma zaborczego. $Z$ kolei ostatni ze szkiców o tematyce średniowiecznej związany jest z rozwojem polskiego oratorstwa i kaznodziejstwa w tym okresie. W przypadku kazań Stanisława ze Skarbimierza dla Koehlera istotne okazują się te fragmenty jego dzieł, w których duchowny zestawiał porządek ustrojowy w państwie z prawem Bożym. To ostatnie sankcjonowało ważkość sprawiedliwości, a z tego wynikało kierowanie się tą cnotą przy sprawowaniu władzy państwowej. Część średniowieczną Punktów krystalizacji dopełnia temat władzy królewskiej i relacji monarchy z poddanymi w pismach Pawła Włodkowica. Ważne są tu spostrzeżenia o prawie służącym doskonaleniu obyczajów, godności człowieka i wolnej woli, za którą winny iść wybory i decyzje.

Część renesansową otwierają dwa szkice o poetach nowołacińskich-Mikołaju Hussowskim i Klemensie Janickim. W słynnej Pieśni o żubrze, którą czytał i wykorzystywał Adam Mickiewicz, prezentując litewską florę i faunę w Panu Tadeuszu, $\mathrm{K}$. Koehler stara się dostrzec nie tyle elementy wspólne dla kultury polskiej i europejskiej (popis erudycji, obecność tradycji klasycznej, piękno łaciny), ile raczej odmienność „,wtopioną i kulturowo, i politycznie w dzieje Europy - z pewnym zadaniem, jasno stawianą i eksplikowaną mocnym głosem wizją swojej niezależnej podmiotowości" (s. 82). Inną wartość badacz dostrzega w liryce elegijnej Janicjusza. W tym przypadku skupia się na artykułowanych przez poetę trudach egzystencji, ujawnionych w zbiorze Tristia. Zmaganiom z nieuleczaną chorobą wielkopolskiego liryka towarzyszy jednak etyczna dzielność, którą plebejski twórca ujawnił w szeregu elegii o nachyleniu biograficznym ${ }^{6}$.

Kategoria wolności stanowi dominantę eseju o trybunie republikanizmu, czyli Stanisławie Orzechowskim. Co ciekawe, K. Koehler nie dokonuje tu rekapitulacji treści ważniejszych dzieł autora Policyi, lecz skupia się na znaczeniu retorycznej perswazji jako kluczu modelowania światopoglądu duchownego. Do tego wykorzystuje sławetną „suplikację” do papieża Juliusza III, którego Orzechowski

\footnotetext{
${ }^{5}$ Anonim tzw. Gall, Kronika polska, tłum. R. Grodecki, oprac. M. Plezia, Wrocław 1996 („Biblioteka Narodowa”, Seria I, nr 59), s. 11.

${ }^{6}$ Badacz powołuje się przy tym na inspirację książką Zygmunta Kubiaka Przestrzeń dziet wiecznych. Eseje o tradycji kultury śródziemnomorskiej, Kraków 1993.
} 
poucza na temat odstępstwa od celibatu: „Nie myśl sobie, Juliuszu, że wolno Ci w Polsce to samo, co wolno Ci we Włoszech, gdzie jedno Twoje słowo może ludzi na wygnanie skazać”. Kolejny szkic dotyczy dorobku pisarskiego Piotra Skargi - a właściwie jego stosunku do innowierców zagrażających, jak chciał jezuita, spójności wewnątrzstanowej ${ }^{7}$. W reformacji królewski kaznodzieja widział niebezpieczny potencjał skutkujący rozpadem późnofeudalnej struktury polityczno-społecznej. Remedium na to miała okazać się silna władza centralna, której towarzyszyć powinny stany sejmujące: senat i sejm (koncepcja równowagi w zakresie decyzyjności). Koehler sceptycznie ocenia ideę promowania „staropolskiego ładu", jaką zawarł w swojej prozie kontrreformacyjnej Skarga. Nie był to bowiem czas, by dało się wzmacniać władzę królewską.

Gniazdo i sumienie oraz Kochanowski, obyczaje, polityka i sprawiedliwość to szkice poświęcone autorowi Odprawy postów greckich. Pierwszy esej przywodzi na myśl książkę badacza sprzed kilkunastu lat, gdzie podjął temat „domku szlacheckiego". U Kochanowskiego sarmacki dom staje się metaforą bezpiecznej egzystencji, której gwarantem jest Boże błogosławieństwo. Wyartykułowane we fraszce Na dom w Czarnolesie przekonanie o korelacji zdrowia, czystego sumienia, a przy tym zgody na przemijanie okazuje się apoteozą szlacheckiego „gniazdowania", skojarzonego z niezależnością ekonomiczną i moralną. Kwestii wolnego sumienia i jego współzależności z wolnością szlachecką dotyczy też kolejny szkic. Tym razem badacz dokonał eksplikacji wybranych utworów o tematyce społeczno-obyczajowej i politycznej, dostrzegając w tym nurcie twórczości Kochanowskiego „idealizm aksjologiczny”, charakterystyczny dla renesansowej poezji dydaktycznej.

Z bogatego dorobku pisarzy barokowych autor Punktów krystalizacji wybrał Gofreda albo Jerozolime wyzwolonq Piotra Kochanowskiego, sielanki Szymona Zimorowica, lirykę Wespazjana Kochowskiego, wybrane utwory Wacława Potockiego i pamiętniki Jana Chryzostoma Paska. Te fragmenty książki wypada uznać za szczególnie wartościowe, gdyż badacz nie stroni od oryginalnych tez oraz interpretacji, niekiedy prowokujących do dyskusji, jednak w sumie przekonujących i udokumentowanych. Właściwie cały wywód Koehlera rozciąga się między biegunami europejskości a rodzimości. Niekiedy zresztą te perspektywy subtelnie się przenikają, jak na przykład w eksplikacji Gofreda, skojarzonego ze zmaganiami polsko-tureckimi, zatem aktualizowanego na gruncie sarmackim. Tu pojawia się pytanie: ile w utworze Tassa-Kochanowskiego znajduje się Sarmacji w Europie, a ile Europy w Sarmacji - w gruncie rzeczy jest to zagadnienie dotyczące zakorzenienia we wspólnej tradycji kulturowej, podobnych doświadczeniach militarnych konfrontacji na przestrzeni wieków. Podobnie konceptualizowana jest spuścizna Kochowskiego, utrwalającego mit przedmurza chrześcijańskiego, gdzie powinność patriotyczna uzupełnia obowiązki służenia chrześcijaństwu. I wreszcie

\footnotetext{
${ }^{7}$ Szerzej zob. K. Koehler, Boży podżegacz. Opowieść o Piotrze Skardze, Warszawa 2012.

${ }^{8}$ K. Koehler, Domek szlachecki w literaturze polskiej epoki klasycznej, Kraków 2005.
} 
wolnościowe dyskursy Zimorowica i Potockiego - dla tego pierwszego będzie to perspektywa egzystencjalna, wynikająca, podobnie jak u Janicjusza, z ciężkiej choroby, dla drugiego inna, raczej szlachecka i bliższa czarnoleskiej perspektywie twórczej niezależności. Zwieńczeniem rozważań części staropolskiej okazuje się „narracja tożsamościowa” Paska. Jak zauważył badacz: „narracja XVII-wiecznej opowieści pamiętnikarskiej, stanowiąc efekt wolności obywatelskiej (wolności wyrażania się, wolności wypowiedzi, autoekspresji itp.), była jednocześnie emanacją kultury aktywnej, może nawet buńczucznej, może agresywnej, kultury, której wolność (jako zasada wyrażania się ludzkiej osoby) była fundamentem" (s. 240).

Jak zaznaczono, podsumowanie książki stanowią dwa szkice: o Karpińskim i o Mickiewiczu. Krzysztof Koehler domyka zatem swój wywód pytaniem o kontynuacje idei „polskości” w kolejnych wiekach. Krytycznie wybrzmiewa tu zwłaszcza ocena „obywateli”, których autor Ody do Repnina opisuje jako niewolników na rosyjskich rautach i balach. Jednak rozprawa autora Punktów krystalizacji kończy się pozytywnym wydźwiękiem. Dziady Mickiewicza stanowią dla humanisty dowód na zarysowanie odważnej wizji polskości, opartej na duchowym znaczeniu obrzędu. W nim właśnie skupia się tradycja polskiego losu skumulowanego ludzkiego doświadczenia.

Praca Krzysztofa Koehlera stanowi interesujące ujęcie kulturowe tematyki tożsamościowej. W dobie relatywizacji oceny polskiej historii warto sięgnąć po pracę, dla której fundamentem są solidna wiedza humanistyczna oraz autorski dystans do nowinek metodologicznych. 